Vol. 3, No. 01; 2020

ISSN: 2581-4664

\title{
INTRINSIC MOTIVATION AND PERSONAL VALUE IN PREDICTING THE JOB SATISFACTION AND EMPLOYEE PERFORMANCE : STUDY IN MARINE AND FISHERIES DEPARTMENT OF ACEH JAYA
}

\author{
Sunardi, Muhammad Adam and Teuku Roli Ilhamsyah Putra \\ Department of Management, Universitas Syiah Kuala, Indonesia \\ http://doi.org/10.35409/IJBMER.2020.3134
}

\begin{abstract}
This study is to test the effect of intrinsic motivation and personal value on job satisfaction and employee performance. This research is conducted in Aceh Jaya Marine and Fisheries Department, with the population is its employees as much as 121 people. The sample is taken with census method, so it is equal to the number of population of 121 people. The verification test uses using structural equation modeling (SEM) as a data analysis method with the help of AMOS programs. The result shows that : The result shows that : intrinsic motivation effects job satisfaction significantly; personal value effects job satisfaction significantly; intrinsic motivation effects employee performance significantly; personal value effects employee performance significantly, and; job satisfaction effects employee performance significantly. These hypothesis tests can be updates of causality theories, an references for the next research model. These all also have an implication to the organization related to be more consider about the variables in this research. The originality lies in the integration of the model from the previous research, and uses SEM method as a statistical test approach. The limitation lies in the number of variables that are only four, and with one object.
\end{abstract}

Keyword: Intrinsic motivation, personal value, job satisfaction, employee performance.

\section{INTRODUCTION}

The Aceh Jaya Marine and Fisheries Departmeng strives to improve the performance of the main tasks and functions through activities, programs and policies even though in its journey there are obstacles and limitations. There were several targets that were not reached optimally. Constraints faced in the field are also caused by the limited quality of human resources

Human resources play an important role in determining the progress of a company or organization. According to (Ling, Lo, Sing, \& Ayob, 2011) human resources are the most important assets for organizations and organizations must have leaders who are able to lead and motivate employees to achieve organizational goals. Human resources must play an active role and have high competence in order to achieve company goals. (Aminul Islam, Aktaruzzaman Khan, Obaidullah, \& Syed Alam, 2011) stated that the success rate of a company can be seen from the company's performance in managing its resources. Companies with good performance, have effectiveness in handling human resources, set 


\section{International Journal of Business Management and Economic Review}

Vol. 3, No. 01; 2020

ISSN: 2581-4664

goals that must be achieved both individually and in their organizations.

According to (Abdullah \& Tantri, 2012) employee performance is defined as a result of one's efforts achieved by the existence of effort, ability, and perception of tasks. This effort is the result of motivation, satisfaction, and organizational commitment that shows the amount of energy (physical and mental) used by an individual in starting a task. Business is an individual characteristic in carrying out tasks. Efforts are usually not directly affected in the short term period. (Kurniawan, 2012) stated that employee performance is as a work achievement or work result both in quality and quantity achieved by employees per period in carrying out their duties. There are two factors that affect the employee performance, namely internal factors and external factors. Internal factors are factors related to a person's characteristics, including attitudes, personality traits, physical traits, desires or motivations, age, sex, education, work experience, cultural background and other personal variables. External factors are factors that influence employee performance that come from the environment, motivation, actions of coworkers, and social environment (Lamidi, 2008).

The performance of employees at the Marine and Fisheries Service of Aceh Jaya Regency is the result of work in the quality and quantity achieved by their employees in accordance with their fields of duties and responsibilities. Based on observations by the authors, it turns out that employees of Aceh Jaya Marine and Fisheries Department still do not show the performance as expected by the leadership or community expectations, especially in community services in the field of community empowerment which has a livelihood in the field of freshwater fisheries.

Based on the phenomenon that occurred, there is related to the low level of personnel job satisfaction caused by factors that are still low compensation received by the employees of the Aceh Jaya Marine and Fisheries Department. Other than that, the low personal value also influences the satisfaction of employee and their performance.

The underlying phenomenon of this research is the low performance of the Aceh Jaya Marine and Fisheries Department, which is indicated by the low budget absorption in 2017, as a whole, only $69.79 \%$, while the realization of 2016 reached $70.55 \%$ based on all items of financial realization includes indirect expenditure, direct expenditure, employee expenditure, goods and services expenditure and capital expenditure. The low performance of the Aceh Jaya Marine and Fisheries Department is caused by the low job satisfaction of employees, that is influenced by intrinsic motivation and personal value.

Low employee performance can be caused by motivational problems within a company (Sadikoglu \& Zehir, 2010). The research conducted by (Anggrainy, Darsono, \& Putra, 2017) proved that motivation effects the increase in employee performance. Motivational factors that will influence the performance of a potential people, where a person is not necessarily willing to mobilize all of his potential to achieve optimal results, so there is still a need for drivers to effect employees to use all his potential (Elma, 2013)). Organizations must motivate their employees to achieve organizational goals, even motivation is the best tool to improve performance (Zameer, Alireza, Nisar, \& Amir, 2014). Motivation is an encouragement to a series of processes of human behavior on achieving goals (Wibowo, 2012). Motivation does not only come from the leader (external) but also to the employee (internal) that is used to launch the existing work, with motivation from himself and the leadership of the employees, the goals desired by the company can be achieved well, so that employee performance becomes more increase (Vidianingtyas \& Putri, 2014).

According to (Luthans, 2012) intrinsic motivation is defined as a motivation that 


\section{International Journal of Business Management and Economic Review}

Vol. 3, No. 01; 2020

ISSN: 2581-4664

encourages someone to have an achievement in the individual, better known as motivational factors. (Prahiawan \& Simbolon, 2014) stated that the most powerful motivation is intrinsic motivation because it is embedded directly in employees. Through intrinsic motivation makes employees aware of their better responsibilities and work and they are encouraged to be passionate about completing their jobs well. Work results because awareness creates good performance and employees will realize that by having a good performance, they will be able to fulfill their needs. This is in accordance with the research conducted by (Lukito, Puspito, Haryono, Tri, \& Warso, Mukeri, 2016) which shows that intrinsic motivation has a positive effect on employee performance. This means that if intrinsic motivation is increased, then employee performance increases. The results of these studies support the results of research by (Risqi, Saleh, \& Prihatini, 2016) shows that intrinsic motivation has a positive and significant effect on employee performance.

\section{LITERATURE}

\section{Organizational Performance}

Organizational performance is the totality of the work achieved by an organization. The performance of an organization can be seen from the extent to which the organization can achieve goals based on predetermined goals (Sujardi, 2009). Regarding the difficulties that occur in measuring the performance of public organizations, (Dwiyanto, 2012) stated the difficulties in measuring the performance of public service organizations arise partly is because the goals and mission of public organizations are often not only runaway but also multidimensional. Public organizations have more complex stakeholders than private organizations. Stakeholders from public organizations often have interests that clash with one another, as a result the size of the performance of public organizations in the eyes of stakeholders also becomes different.

\section{Job satisfaction}

According to (Davis \& Newstrom, 1993) in (Mangkunegara, 2013) job satisfaction is the favorableness or unfavorableness with employees 'view of their work. job satisfaction is a feeling of supporting or not supporting the experienced employees in work. (Pushpakumari, 2008) defined job satisfaction is the way an employee feels about his or her job. The research conducted by (Nasution, Musnadi, \& Faisal, 2015) proved that job satisfaction effects employee performance improvement.

Employees will feel satisfied in working if the aspects of work and themselves support. Along with the development of technology that is growing very rapidly, but human resources still play an important role. According to (Baldwin, 1919) the human element plays an important role in the process of a job. He stated that however perfect plans, organizations, supervision and research, if they are unable to carry out their duties with interest and happiness then a the company will not achieve as much results as can actually be achieved. Basically, each individual has different levels of satisfaction, according to the values applied to him. job satisfaction is also a person's feelings for the work they are doing. So job satisfaction itself is related to employee expectations and what is obtained from work.

\section{Intrinsic Motivation}




\section{International Journal of Business Management and Economic Review}

Vol. 3, No. 01; 2020

ISSN: 2581-4664

Intrinsic motivation comes from within. It is needed every day to run a life, help others, lead a group of people and to achieve their desired goals. Motivation comes from the word "move" (latin), which means encouraging or moving (Robbins \& Coulter, 2016). Motivation is all the strength that is in a person who gives power, direction and maintains the behavior in question. In our daily lives, motivation is defined as the whole process of giving encouragement or stimulation to employees, so that they are willing to work without feeling forced (Herzberg, Mausner, \& Snyderman, 2011). (Herzberg et al., 2011), declared motivation is a psychological process that reflects the interaction between attitudes, needs, perceptions and decisions that occur within oneself. According to (Robbins \& Coulter, 2016), motivation is the willingness to direct all efforts to achieve organizational goals that are influenced by the ability of the business to satisfy some individual needs. (Herzberg et al., 2011), stated that motivation is a psychological process that takes place in interactions between different personalities to meet human needs. From this process the impulse (motive) results in the willingness and desire to act through decision making.

According to (Herzberg et al., 2011) motivation is giving the driving force that creates the excitement of one's work, so that they will cooperate, work effectively and integrate with all their efforts to achieve satisfaction. The American Encyclopedia in (Hagemann, 2013) defined motivation as a tendency in a person who increases endurance and directs his behavior. Motivation includes factors of emotional and biological needs, which can only be predicted from observing behavior. While the notion of work, according to (Hagemann, 2013), is a number of physical and mental activities to do a job. The research conducted by (Husni, Musnadi, \& Faisal, 2017) proved that work motivation possessed by employees has an influence on increasing employee job satisfaction.

\section{Personal Value}

Philosophers and social scientists have known the importance of values in the social sciences, but there are not many business scholars who recognize how important values are for individuals, social, and social change (Kahle \& Kennedy, 1989). The influence of personal values concepts on behavior has been investigated in several scientific disciplines such as marketing (Kahle, Beatty, \& Homer, 1986) and the field of psychology (Rokeach, 1973). Some marketing scientists have believed in personal values derived from one's development through activities they are citizens and through their behavior as consumers (Leng \& Botelho, 2010).

\section{Research Model and Hypothesis}

From the discussion above, the authors formulate the research model and hypothesis as follows : 


\section{International Journal of Business Management and Economic Review}

Vol. 3, No. 01; 2020

ISSN: 2581-4664

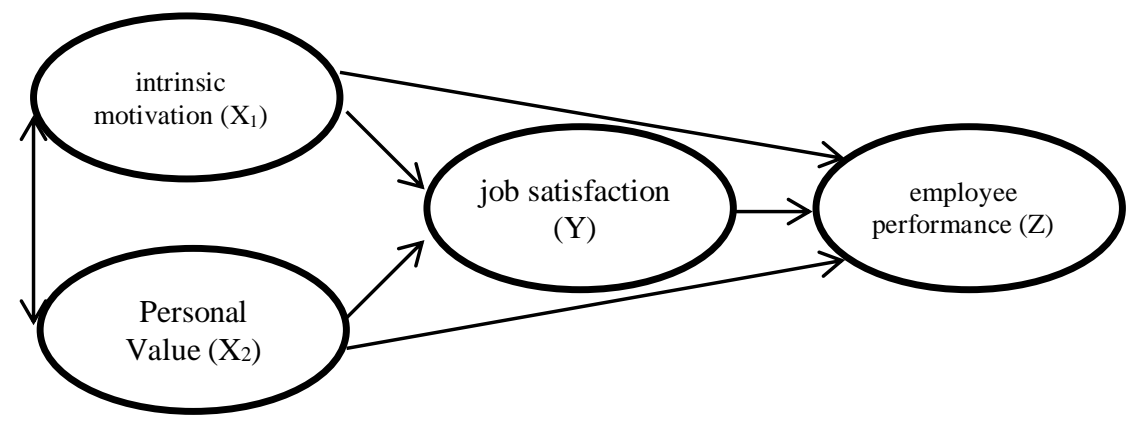

Figure 1. Research Model

H1 : intrinsic motivation effects job satisfaction significantly;

$\mathrm{H} 2$ : personal value effects job satisfaction significantly;

$\mathrm{H} 3$ : intrinsic motivation effects employee performance significantly;

H4 : personal value effects employee performance significantly, and;

H5 : job satisfaction effects employee performance significantly.

\section{METHOD}

This research is conducted in Aceh Jaya Marine and Fisheries Department, with the population is its employees as much as 121 people. The sample is taken with census method, so it is equal to the number of population of 121 people. The authors built constructs to measure each variable based on the previous theories, that are : 1) for intrinsic motivation : status and responsibilities, sdequate benefits, working environment conditions, work facilities, and personal desires and expectations; 2) for personal value : mastery of work, like to work, responsible, ability to predict, ability to overcome threats, and the past experience; 3 ) for job satisfaction : happiness, partner relations, relationships with leaders, overcoming burnout, respect, and feel comfortable, and; 4) for employee performance : understanding of duties and functions, work innovation, working speed, work accuracy, cooperation, facilities, convenience, and openness.

Data is analyzed by Structural Equation Modeling (SEM) using the Amos 22 program. SEM is a set of statistical technique that allows testing of a relatively complicated set of relationships simultaneously (Ferdinand, 2006). The appearance of a complicated model has the effect that in reality the management decision-making process is a complicated process or is a multidimensional process with various patterns of tiered causality. Therefore we need a model as well as an analytical tool that can accommodate multidimensional research. SEM is able to enter latent variables into the analysis. Latent variables are unobserved concepts that are approximated by observed or measured variables obtained by respondents through data collection methods (survey, test, observation) and often called manifest variables (Ghozali, 2017).

\section{RESULT}

The results for full analysis of SEM model is shown in Figure 1. 
Vol. 3, No. 01; 2020

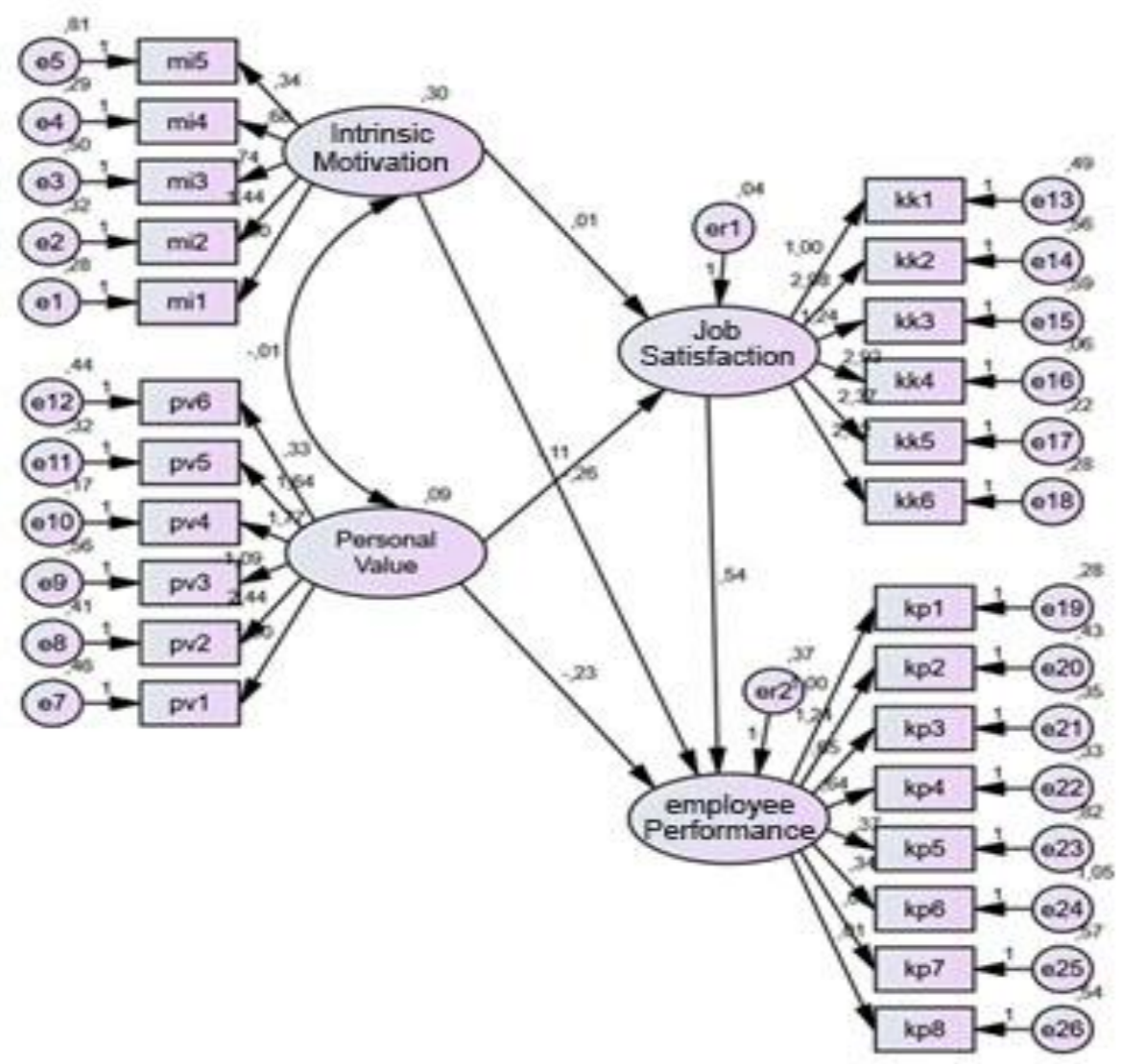

Figure. 2. Structural Equation Model (SEM)

\section{H1 is accepted : the effect of Motivation on job satisfaction}

The result test of the effect of motivation on job satisfaction shows a CR value 6.502 and a probability 0.000 . Both of these values meet the requirements for Ha1 acceptance, namely the CR value 6.502 which is greater than 1.97 and a probability smaller than 0.05 so that Ha1 is accepted and Hol is rejected. So it explains that the intrinsic motivation of the employees of the Marine and Fisheries Department of Aceh Jaya Regency has a significant effect on their job satisfaction.

H2 is accepted : the effect of Personal value on job satisfaction 
Vol. 3, No. 01; 2020

ISSN: 2581-4664

The result test of the effect of personal value on job satisfaction shows a CR value 6.631 and a probability 0.000 . Both of these values meet the requirements for Ha2 acceptance, namely the CR value 6.631 which is above 1.97 and the probability is below 0.05 , so that $\mathrm{Ha} 2$ is accepted and Ho2 is rejected. so it indicates that the personal value applied by employees of Aceh Jaya Marine and Fisheries Department has a significant effect on their job satisfaction.

\section{$\mathrm{H3}$ is accepted : the effect of intrinsic motivation on employee performance}

The result test of the effect of motivation on employee performance shows a CR value 4.494 and with a probability 0.000 . Both of these values meet the requirements for Ha4 acceptance, namely a CR value of 4.494 which is above 1.97 and a probability below 0.05 , so that $\mathrm{Ha} 4$ is accepted and Ho4 is rejected. Thus it figures that motivation has a significant effect on the performance of employees of Aceh Jaya Marine and Fisheries Department.

\section{H4 is accepted : the effect of personal value on employee performance}

The result test of the effect of personal value on employee performance shows a CR value 2.437 and a probability of 0.000 . Both of these values meet the requirements for Ha5 acceptance, namely the CR value of 2.437 which is above 1.97 and the probability is below 0.05 , so that Ha5 is accepted and Ho5 is rejected. Thus it describes that the personal value applied by all employees of Aceh Jaya Marine and Fisheries Department has a significant influence on improving their employee performance.

\section{H5 is accepted : the effect of job satisfaction on employee performance}

The result test of the effect of job satisfaction on employee performance shows a CR value 4.876 and a probability 0.000 . Both of these values meet the requirements for Ha3 acceptance, namely a CR value 4.876 which is above 1.97 and a probability below 0.05 , so that $\mathrm{Ha} 3$ is accepted and Ho3 is rejected. So it figures that job satisfaction has a significant effect on employee performance of Aceh Jaya Marine and Fisheries Department.

\section{Managerial Implications}

The result of this study implies that the intrinsic motivation possessed by employees have a positive impact on improving the job satisfaction and the performance of the employees. The increase of job satisfaction based on intrinsic motivation can be seen from the quality of work improvement, because the employees of the Deparment always try to improve the quality of work in accordance with work standards set by the leadership. With the tasks received by employees in accordance with their ability, so that the employees concerned feel able to carry out their duties and responsibilities better.

The result related to personal value is stated that the personal value applied by employees also have a positive impact on improving the job satisfaction of Aceh Jaya Marine and Fisheries Department. This is inline with the previous research by (Rimbani, 2015) which stated that the application of personal values applied to all employees will have a real impact in improving the 


\section{International Journal of Business Management and Economic Review}

Vol. 3, No. 01; 2020

ISSN: 2581-4664

performance of employees. Then the research conducted by (Rahmanto, 2015) stated that personal value has an influence on improving employee performance. The implications of the increase in personal value on job satisfaction and the performance of employees can be seen from the accuracy of employees to come to the office or go home in a timely manner, employees are able to comply with all the rules set by the leaders, so that all work can be realized based on predetermined work targets.

\section{CONCLUSION}

The result shows that : intrinsic motivation effects job satisfaction significantly; personal value effects job satisfaction significantly; intrinsic motivation effects employee performance significantly; personal value effects employee performance significantly, and; job satisfaction effects employee performance significantly. These hypothesis tests can be updates of causality theories, an references for the next research model. These all also have an implication to the organization related to be more consider about the variables in this research, especially for the Marine and Fisheries Department of Aceh Jaya. The originality lies in the integration of the model from the previous research, and uses SEM method as a statistical test approach. The limitation lies in the number of variables that are only four, and with one object.

\section{REFERENCES}

Abdullah, T., \& Tantri, F. (2012). Manajemen Pemasaran. Jakarta: Rajawali Pers.

Aminul Islam, M., Aktaruzzaman Khan, M., Obaidullah, A. Z. M., \& Syed Alam, M. (2011). Effect of Entrepreneur and Firm Characteristics on the Business Success of Small and Medium Enterprises (SMEs) in Bangladesh. International Journal of Business and Management, 6(3), 289-299. https://doi.org/10.5539/ijbm.v6n3p289

Anggrainy, I. F., Darsono, N., \& Putra, T. R. I. (2017). Pengaruh Fasilitas Kerja, Disiplin Kerja Dan Kompensasi Terhadap Motivasi Kerja Implikasinya Pada Prestasi Kerja Pegawai Negeri Sipil Badan Kepegawaian Pendidikan Dan Pelatihan Provinsi Aceh. Jurnal Magister Manajemen, 1(1), 1-10.

Baldwin, H. A. (1919). Holiness and the human element. America: Louisville, Ky., Pentecostal publishing co.

Davis, K., \& Newstrom, J. W. (1993). Perilaku Dalam Organisasi, Jilid 2 (Edisi Ketu). Jakarta: Erlangga.

Dwiyanto, A. (2012). Reformasi Birokrasi Publik di Indonesia (Cetakan Ke). Yogyakarta: Gadjah Mada University Press.

Elma, C. (2013). The Predictive Value of Teacher's Perception of Organizational Justice on Job Satisfaction. Eurasioan Journal of Education, 51, 157-176. 


\section{International Journal of Business Management and Economic Review}

Vol. 3, No. 01; 2020

ISSN: 2581-4664

https://doi.org/10.1192/bjp.111.479.1009-a

Ferdinand, A. (2006). Metode Penelitian Manajemen Pedoman Penelitian untuk Penulisan Skripsi Tesis dan disertai Ilmu Manajemen. In Semarang: Universitas Diponegoro. Semarang: Fakulas Ekonomi dan Bisnis Univ Diponegoro.

Ghozali, I. (2017). Model Persamaan Struktural, Konsep dan Aplikasi dengan Program AMOS 24 Update Bayesian SEM (Edisi 7). Semarang: Badan Penerbit Universitas Diponegoro.

Hagemann, G. (2013). Motivasi untuk Pembinaan Organisasi. Jakarta: PT. Pustaka Binaan Pressindo.

Herzberg, F., Mausner, B., \& Snyderman, B. B. (2011). The Motivation to Work. New Jersey: Transaction Publishers.

Husni, Musnadi, S., \& Faisal. (2017). Pengaruh Lingkungan Kerja, Kompensasi Dan Motivasi Terhadap Kepuasan Kerja Serta Dampaknya Terhadap Loyalitas Kerja Pegawai Rutan Di Provinsi Aceh (Studi Kasus Pada Rutan Klas IIB Banda Aceh Dan Rutan Klas IIB Jantho). Jurnal Magister Manajemen, 1(1), 1-11.

Kahle, L. R., Beatty, S. E., \& Homer, P. (1986). Alternative Measurement Approaches to Consumer Values: The List of Values (LOV) and Values and Life Style (VALS). Journal of Consumer Research, 13(3), 405. https://doi.org/10.1086/209079

Kahle, L. R., \& Kennedy, P. (1989). Using the list of values (LOV) to understand consumers. Journal of Consumer Marketing, 6(3), 5. https://doi.org/10.1108/EUM0000000002549

Kurniawan, I. (2012). Pengaruh motivasi kerja dan budaya organisasional terhadap kinerja karyawan di Universitas Kristen Petra. Universitas Kristen Petra.

Lamidi. (2008). Pengaruh Kepemimpinan Transformasional Terhadap Organizationl Citizenship Behavior:Dengan Variabel Intervening Komitmen Organisasional. Jurnal Ekonomi Dan Kewirausahaan, 8(1), 25-37. https://doi.org/10.1192/bjp.112.483.211-a

Leng, C. Y., \& Botelho, D. (2010). How does national culture impact on consumers' decisionmaking styles? A cross cultural study in Brazil, the United States and Japan. BAR Brazilian Administration Review, 7(3), 260-275. https://doi.org/10.1590/S180776922010000300004

Ling, V. M., Lo, M. chiun, Sing, N. K., \& Ayob, N. B. (2011). The influence of leadership styles on employees' job satisfaction in public sector organization in Malaysia. International Journal of Business, Management and Social Sciences, 2(1), 24-32.

Lukito, Puspito, H., Haryono, Tri, A., \& Warso, Mukeri, M. (2016). Pengaruh Motivasi Instrinsik, Motivasi Ekstrinsik Dan Pegalaman Kerja Terhadap Kinerja Karyawan (Studi pada BTPN Syariah Semarang). Journal of Management, 2(2), 1-15.

Luthans, F. (2012). Organization Behavior An Evidence-Based Approach. In Organizational Behavior: An edivence-Based Approach. Boston: McGraw-Hill.

Mangkunegara, A. P. (2013). Manajemen Sumber Daya Manusia Perusahaan. Bandung: Remaja Rosdakarya.

Nasution, E., Musnadi, S., \& Faisal. (2015). Faktor-Faktor Yang Mempengaruhi Kepuasan Kerja Dan Dampaknya Terhadap Kinerja Pegawai Kanwil Direktorat Jenderal Kekayaan Negara Aceh. Jurnal Magister Manajemen, 9(1), 123-134.

Prahiawan, W., \& Simbolon, N. (2014). Pengaruh Motivasi Intrinsik Dan Lingkungan Kerja Terhadap Kinerja Karyawan Pada PT Intimas Lestari Nusantara. Jurnal Ekonomi Universitas Esa Unggul, 5(1). 


\section{International Journal of Business Management and Economic Review}

Vol. 3, No. 01; 2020

ISSN: 2581-4664

Pushpakumari, M. D. (2008). The Impact of Job Satisfaction on Job Performance : An Empirical Analysis. City Forum, 9(1), 89-105. Retrieved from http://202.11.2.113/SEBM/ronso/no9_1/08_PUSHPAKUMARI.pdf

Rahmanto, M. R. A. (2015). Pengaruh Keputusan Investasi, Keputusan Pendanaan Dankebijakan Dividen Terhadap Nilai Perusahaan Pada Perusahaan Manufaktur Yang Terdaftar Di Bursa Efek Indonesia. Universitas Negeri Yogyakarta.

Rimbani, S. E. (2015). Analisis Pengaruh Motivasi, Disiplin Kerja Dan Komitmen Karyawan Terhadap Prestasi Kerja Karyawan (Study Kasus Rsud Karanganyar). Universitas Muhammadiyah Surakarta.

Risqi, H. B., Saleh, C., \& Prihatini, D. (2016). Pengaruh Motivasi Intrinsik Dan Motivasi Ekstrinsik Terhadap Kinerja Melalui Perilaku Kerja Karyawan Honorer Hotel Dan Pemandian Kebonagung Jember (The Effect Of Intrinsic Motivation And Extrinsic Motivation Towards The Performance Through Work Behavior E. Digital Repository Universitas Jember. Retrieved from http://repository.unej.ac.id/handle/123456789/78345

Robbins, S. P., \& Coulter, M. (2016). Manajemen (ed. 13). Jakarta: Erlangga.

Rokeach, M. (1973). The nature of human values. New York: Free Press.

Sadikoglu, E., \& Zehir, C. (2010). Investigating the effects of innovation and employee performance on the relationship between total quality management practices and firm performance: An empirical study of Turkish firms. International Journal of Production Economics, 127(1), 13-26. https://doi.org/10.1016/j.ijpe.2010.02.013

Sujardi. (2009). Pengembangan Kinerja Pelayanan Publik. Bandung: Refika Aditama.

Vidianingtyas, R. N., \& Putri, W. H. (2014). Pengaruh Kompensasi, Kepuasan Kerja, Motivasi Kerja Dan Gaya Kepemimpinan Terhadap Kinerja Karyawan Pada Perusahaan Jasa Catering Di Daerah Istimewa Yogyakarta. Efektif. Jurnal Bisnis Dan Ekonomi, 5(1), 99110.

Wibowo. (2012). Budaya Organisasi: Sebuah Kebutuhan untuk Meningkatkan Kinerja Jangka Panjang (Edisi Kedu). Jakarta: Rajawali Pers.

Zameer, H., Alireza, S., Nisar, W., \& Amir, M. (2014). The Impact of the Motivation on the Employeeâ $\square \mathrm{TM}_{\mathrm{S}}$ Performance in Beverage Industry of Pakistan. International Journal of Academic Research in Accounting, Finance and Management Sciences, 4(1), 293-298. https://doi.org/10.6007/ijarafms/v4-i1/630 